\title{
Influence of Excessive Expenditure of the Government in Perspective of Interest Rate and Money Circulation Which in Turn Affects the Growing Process in Pakistan
}

\author{
Zia-Ur- Rahman \\ Department of Economics, Preston University, Pakistan \\ Email: ziaurrehman@preston.edu.pk Tel:+923064939339
}

\begin{abstract}
In this study an attempt was made to investigate the affiliation among the excessive expenditure, interest rate, inflation, money supply and growing rate. For this purpose, time series data comprises 1976 to 2018 were collected from the Handbook and world development indicator. The analyses show a good number of findings. Firstly, the unit root test results show that all the variables are stationary at level, except inflation but appear stationary at first difference. However, ZA test pronounces structural break in the data with a different time period. This of course leads the study to determine the short and long-term association among the variables. The vector error correction and Johansen cointegration reveals the short and long-run relationship exists among the variables. While excessive expenditure and the money circulation have one-way granger causality with the growth rate. Moreover, the diagnostic and stability tests describe that model specification, auto correlation and model are normal. Even impulse response pronounces that all the variables would have a positive influence on the growth rate in the future. Based on this, the study recommends that government should not create the atmosphere of the crowding out. No doubt interest rate favors the economy, but government should also manage its expenditure.
\end{abstract}

Keywords: Money circulation, Expenditures, Interest rate, Granger causality, Impulse response and growth rate.

JEL Classification: E12; E43; E51; E62.

Citation | Zia-Ur-Rahman (2019). Influence of Excessive Expenditure of the Government in Perspective of Interest Rate and Money Circulation Which in Turn Affects the Growing Process in Pakistan. Asian Journal of Economics and Empirical Research, 6(2): 120-129.

History:

Received: 18 June 2019

Revised: 24 July 2019

Accepted: 28 August 2019

Published: 11 October 2019

Licensed: This work is licensed under a Creative Commons

Attribution 3.0 License (cc)

Publisher: Asian Online Journal Publishing Group
Funding: This study received no specific financial support.

Competing Interests: The author declares that there are no conflicts of interests regarding the publication of this paper.

Transparency: The author confirms that the manuscript is an honest, accurate, and transparent account of the study was reported; that no vital features of the study have been omitted; and that any discrepancies from the study as planned have been explained.

Ethical: This study follows all ethical practices during writing.

\section{Contents}

1. Introduction

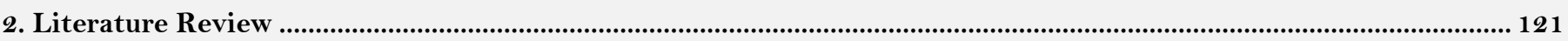

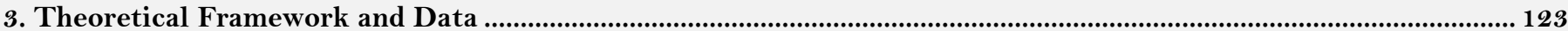

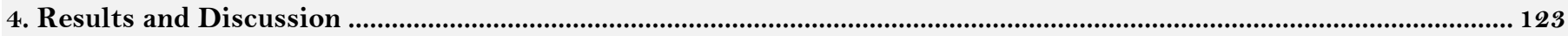

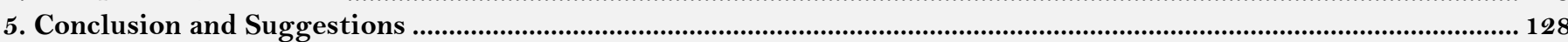

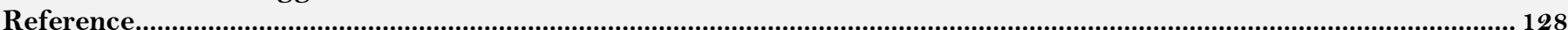




\section{Contribution of this paper to the literature}

This study contributes to the existing literature by analyzing the monetary policy incorporated with one fiscal factor which leads the economy towards the prosperity.

\section{Introduction}

Earning and spending of the government play a pivotal role in the growth process either it is developed country or the emerging economy. And when expenditure level goes up in context to the earnings creates a situation named excessive expenditure which is very bad for the economy. And also creates shock wave which hits the economy one after the another, destabilize the economy, deficiency of funds, the rise of interest rate which in turn influenced the growing process (Kirchner, 2007; Tabar et al., 2016).

Keynesian economists are in the favor of government intervention to resolve the market imbalance by increasing the government expenditure or money supply to assist the economy from recession. Meanwhile, Keynesian rely on the interest rate, use shocks to influence the growing process. On the other hand, classical economist says that all the resources are fully utilized so there in no room for government intervention (Saymeh and Orabi, 2013).

To fulfill expenditure, up rises in taxation reduce the profit of the firm and discourages new investment which in turn reduce the demand of the loanable funds and reduce the interest rates. While money supply is the total amount of the money in circulation and liquid instruments in a specific time period. Money supply is further break down in money supply one, money supply two and money supply three. This study utilizes the M2. The money supply is reflected to be measured, to regulate the interest rate and also affects the economy.

Keynesian model consists of three factors, consumption, investment and government expenditure like $\mathrm{Y}=\mathrm{C}+$ $\mathrm{I}+\mathrm{G}$. However, in the study is perspective of $\mathrm{G}$ which represents the government expenditure. When government expands its spending, then it creates the same effect produced by the investment because the government may be increasing some sort of public expenditure like energy, sanitation etc. Which in turn increase the productivity further promotes the inflationary phenomena (Feldstein, 1982; Eisner, 1992; Tabar et al., 2016) along with excessive expenditure.

In recent past Pakistan encourages and sponsored rigorous enhancement in the growth rate, expenditure, interest rate, money supply and the inflation. Consequently, Pakistan has to face many ups and down in the flow of all the factors, great fluctuation can be seen after 2004 which declines the growth rate even growth rate turns smooth with the passage of time. So, Figure 1 demonstrates an overall picture of macro factors which are present to enhance the growth rate.

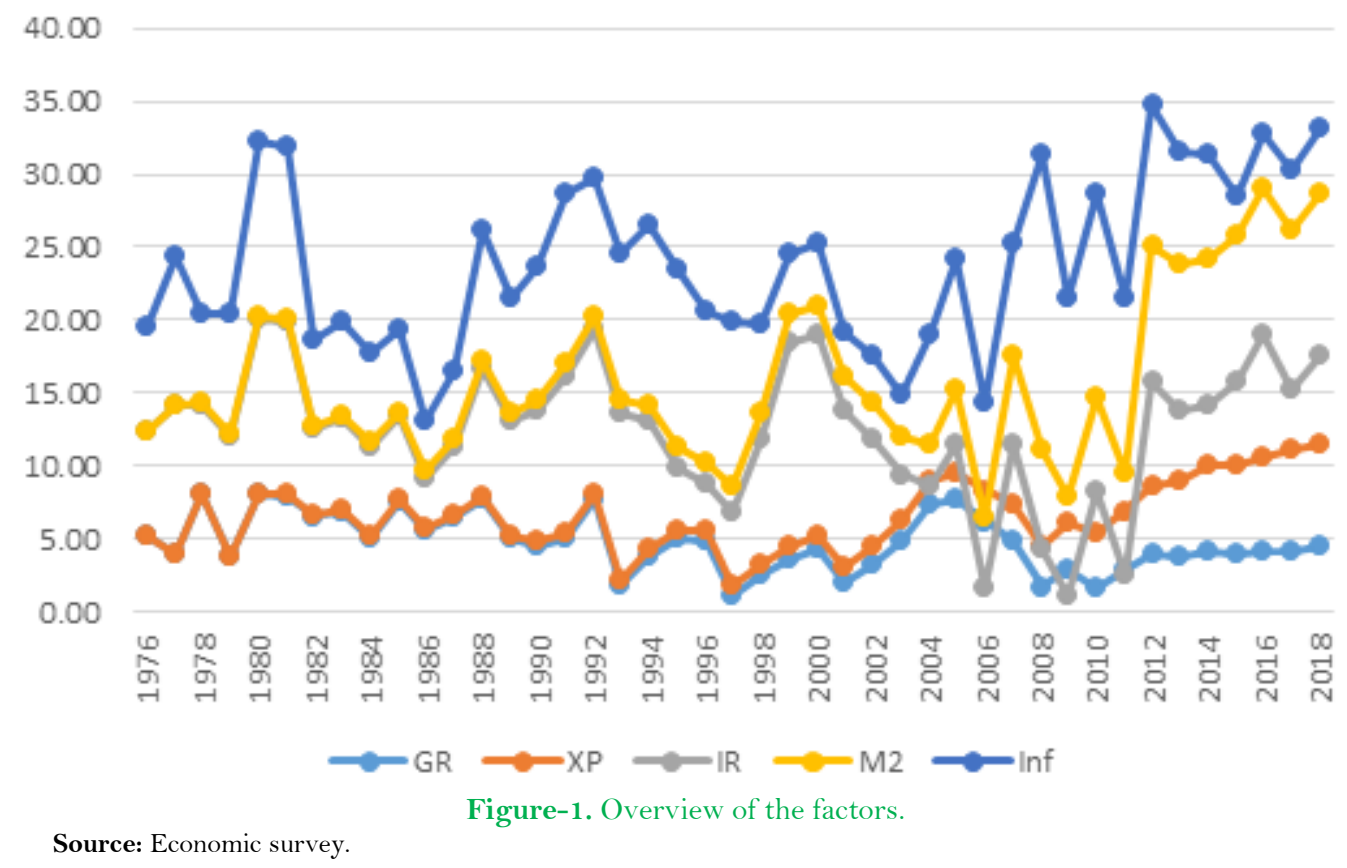

This study is different from the past work on many bases because it incorporated the structural break in the data which was missing in the literature. And utilizes the Granger causality which factor granger causes the other factor in what direction (uni-direction/bi-directional). Also illustrates the fluctuating behavior of the variables which generates a shock wave to destabilize the growth rate in the future. Eventually, predict the trend, pattern or the behavior either it responds positively or negatively. However, the rest of the paper comprises the literature review, methodology, result and discussion and the conclusion with the policy suggestions.

\section{Literature Review}

Money in circulation, interest rate and excessive expenditure are the pivotal variables of the monetary and fiscal policy and also play very important role in the development either it is developing country or the developing country.

Muñoz et al. (1985) states that excessive budget expenditure and current anticipated deficit have effects on the production but in the long term. Munoz concluded these results on the basis of multi regression equation for the American economy, while employing the interest rate and excessive expenditure. Nwaogwugwu and Evans (2016) confirms the crowding out the phenomena in the USA economy. And also states that excessive expenditure and interest rate are connected, and also capture a direct association between interest rate and excessive expenditure if one goes up second variable also goes up. While Hubbard (2012) says that if the 1 percent increase of debt of the 
government increases it will also increase the interest rate. Hubbard explore the connection on the basis of vector auto regression technique and also confirms the Muñoz et al. (1985) findings. Burney et al. (1989) while utilizing the ordinary least square method, state that if the government borrowed to fulfill the capital requirement it directly influenced the interest rate. To overcome the problem of excessive expenditure, government should be used the monetary factor like money supply to counter the hurdle of excessive expenditure (Aqeel et al., 200o). The major factor of excessive expenditure is the crowding out of the non-public investment because it has long term association with interest rate, however GDP and an increase in prices are influenced by the interest rate positively (Herbert and Saher, 2010).

The fluctuation in excessive expenditure casing interest rate in the South Africa, but spending does not cause the treasury bills while treasury bills and interest rate are interlinked. The excessive expenditure changes the interest rate, which indirectly influenced the investment (Gupta and Uwilingiye, 2008). While Ramey (2011) determines the excessive expenditure is causing interest rate and needs to be controlled. In the perspective of neoclassical framework, Kameda (2008) states that the nexus between interest rate and excessive expenditure in Japan economy. And also explore the excessive expenditure has more influenced on the interest rate in the context to the government debt.

While in the perspective of Pakistan economy, in different time period the researches try to capture the interlink between interest rate and excessive expenditure. And found that the causes of all major economic problems in Pakistan are due to the interest rate and excessive spending. The decades of 70, 80, 90 \& oo provides enough evidence to confirm that the problematic factor is the excessive expenditure. And there is also a short as well as long term correlation among the interest rate, current deficit and excessive expenditure.

However, the Ricardian equivalence hypothesis does not hold in the Pakistan economy, because interest rate, public debt and excessive expenditure are correlated in the long term (Waqas and Awan, 2012). The excessive expenditure directly affects the interest rate (Rangarajan and Srivastava, 2005). Moreover, Chakraborty (2012) conducted a study to capture the association between excessive expenditure and interest rate, which leads a situation of the crowding out. While, Purusothaman (2013) since 1970 it is noted that in the Nigerian economy, excessive expenditure is correlated with interest rate in the short term as well as in the long term. In other worlds Keynesian views, on the government spending and interest rate holds in the Nigerian economy.

While, keeping in the view of co-integration of interest rate and excessive expenditure, it is advised that a monetary policy and fiscal policy mix would be employed to stabilize the investment and the interest rate in the Nigerian economy. Under the consideration of "loanable fund theory" Bonga-Bonga (2012) and Noula (2012) are on the same page. They state, the influence of tremors in the budget deficit, like an increase in the non- productive spending on nominal interest rates in South Africa, suggested that a policy combination of fiscal and monetary is the crucial for investor to attain a friendly interest rate in the economy.

However, in the context of Pakistan, Haque and Montiel (1994); Burney et al. (1989) to explore the classical opinion on the said factors, the scholars employed a number of variables and retreat with interest and don't investigate any association between excessive expenditure and interest. Under the consideration of these possibilities, Mukhtar and Zakaria (2008) analyze and found that excessive expenditure has no influence on interest rate and therefore the Recardian equivalence do hold in Pakistan. Harmonizing with Haque and Montiel (1994); Burney et al. (1989). Even there is turn in the work of Mukhtar and Zakaria (2008) i.e. GDP ratio was determining the substantial effect and also confirm the granger causality and found the interlinked of excessive spending with the interest rate. Therefore, confirming the Keynesian believed of crowding out, suggesting to curtail deficit and non-productive spending. And they totally ignore the impact of shocks in the context of Pakistan.

The excessive expenditure has important and proportional effect on money supply which in turn affects the inflation, in Iran this phenomenon was observed by the Samimi and Jamshid (2011). And the research ignores the impact of choosing factors on the overall economy. While in Turkey it is found that consist accumulation of debt and excessive expenditure does not cause an increase in siegnorage in another world money is affected by them. And smooth the way to increase the interest rate, which leads the situation of crowding out. So, it is suggested to adopt a policy mix instead of monetary or fiscal one.

According to the Ihsan and Anjum (2013) consumer price index and interest rate have a positively connected with the growth, while inflation has no effect on growth rate. Both denied the tight monetary policy because when central Bank of Pakistan raise the currency circulation all sectors improve consequently, means that there is an overall enhancement in the growing ratio. Due to above mentioned reason the role of money supply as a tool to control the inflation was questionable and new inflation controller and stabilizer factors are required.

Abou (2014) states that money supply is utilized to control the effects of GDP developing ratio and be a collaboration of central bank and government so fiscal policy must be well planned and prepared. But on the other side, Adefeso and Mobolaji (2010) spending of the government paly a very important role in the developmental process in the economy, but is also promoting the inflationary pressure and increase the liquidity in the economy. So, in the context of Cyprus, the government should control its current expenditure and focus on the developmental expenditure to stimulate the growth and economy has no interference for excessive money supply in the short run.

Idris et al. (2016) examination declares that a continuously up-rise in the price of goods which indirectly reduce the purchasing power of the public that's why firstly goods become rare, but with the passage of time availability of goods increases due to the decrease in purchasing power. While Kewal (2012) says the increase in the price level will declines the real income of the society. Santosa (2017) also agrees with both researcher's findings moreover, Santosa says that the price rise in the goods is more than the increase in the wage rate, that's why the level of economy in society declines.

In the context of an above literature review it is concluded that the argument is not convincing on the relation of excessive expenditure and interest rate. As Ari (2012) and Kirchner (2007) explore that the connection of said variables keeps on changing and one cannot depend on the past findings to make policy to counter current problems. That's why this study utilizes the fluctuating approach to capture the influence of shock on explained variables in the perspective of the current situation. Which assist to develop economic model for further studies. 


\section{Theoretical Framework and Data}

\subsection{Theoretical Framework}

The study of Sims (1986) elaborates that GDP, nominal interest rate and excessive expenditure have a contemporaneous influenced by the circulation of the money. Generally expressed in the Equation 1.

$$
A Y_{t}=\beta_{0}+\beta_{1} Y_{t-n}+\varepsilon_{t}
$$

Multiplying both sides with $\mathrm{A}^{-1}$

$$
\mathrm{Y}_{\mathrm{t}}=\mathrm{A}^{-1} \beta_{0}+\mathrm{A}^{-1} \beta_{1} \mathrm{X}_{\mathrm{t}-\mathrm{n}}+\mathrm{A}^{-1} \varepsilon_{\mathrm{t}}
$$

The equation can be written as

While

$$
\mathrm{Y}_{\mathrm{t}}=\mathrm{B}_{0}+\mathrm{B}_{1} \mathrm{X}_{\mathrm{t}-\mathrm{n}}+\mu_{\mathrm{t}}
$$

$$
\mathrm{Y}_{\mathrm{t}}=\left(\mathrm{GDP}_{\mathrm{t}}, \mathrm{NI}_{\mathrm{t}}, \mathrm{EE}_{\mathrm{t}}, \mathrm{MS}_{\mathrm{t}}\right)
$$

In Equation $1 \mathrm{~A}, \beta_{0}$ and $\beta_{1}$ are the coefficient and the Equation 4 elaborates the $\mathrm{Y}_{\mathrm{t}}$. According to the Keynesian the interest rate negatively influences the GDP, due to increase in the interest rate, the investor is discouraged and hence he is no more interested in the investment which in turn decrease the productivity of the economy. Further, they say that expending the government expenditure progressively influenced the economy, but for a while after some time the effect of deficit takes over the positivity.

Keynesian says, when there is an increase in the money supply it will negatively affect the nominal interest rate, means that the interest rate will fall and this decrease is considered to be favorable to borrow, so in this sense money supply is considered to be a policy variable to control and maintain the favorable interest rate for the economy. Moreover, the effect of increase in money supply negatively influenced by the nominal interest, meaning that a decrease in the interest rate is more favorable to borrow that's why here money supply is considered as a policy factor to control and maintain the suitable interest rate.

Schabert (2005) in the framework of "New Keynesian Model" explores that the targets of interest ratio can be achieved, if the circulation of money is non-destabilizing. And circulation of the money should be amplified along with the increase in the gross domestic product so that it can fluctuate the interest rate. While the interest rate is affected by the excessive expenditure and this effect is also depends on the lower tax ratio. In other words, anticipated fiscal deficit affects the interest rate. According to the Jillani and Asim (2010) growth rate is affected by the nominal interest rate and money supply and Karapetyan and Harutyunyan (2013) suggest that excessive expenditure influence the GDP growth rate this can be expressed as in Equation 5.

$$
\mathrm{GDP}=f(\mathrm{Ni}, \mathrm{Ms}, \mathrm{Ee})
$$

But the relation "i" not deterministic as given above, there are also observant of the reverse causality. There are also cases of causality between money supply, nominal interest rate and excessive expenditure. While Muelbauer and Nunziata (2001) observes that nominal interest rates affect the economy. While reforming the Jillani and Asim (2010) and Karapetyan and Harutyunyan (2013) model we design a new one as expressed in the Equation 6.

$$
\mathrm{GR}=f(\mathrm{XP}, \mathrm{IR}, \mathrm{M} 2, \mathrm{Inf})
$$

Where GR stands for the growth rate, XP for the excessive expenditures, IR for the interest rate, M2 for the money supply/money circulation and Inf for the inflation prevailing in the economy.

\subsection{Data}

The time series data of all the variables such as excessive government expenditure (XP), interest rate (IR), money in circulation (M2), inflation (Inf) and gross domestic product proxy for the growth rate (GR) are collected from the Handbook of Statistics, World Development Indicator and the International Financial Statistics comprises on the 1978 to 2018.

\section{Results and Discussion}

To find out the basic features of the data, descriptive analyses are utilized. Table 1 illustrates the overview of all the factors included in this study for the period 1978-2017. Which shows that the average growth rate in Pakistan is the Million dollars 1.48 which lies between the 2.08 to 0.01 and expenditure is the -0.58 Million dollars, while the average value of IR, M2 and Inf were 1,87, 0.14 and 1.91 respectively.

Table-1. Descriptive review of the variables.

\begin{tabular}{l|c|c|c|c|c|c|c|c}
\hline Factors & Mean & Median & Maximum & Minimum & Std. dev. & Skewne & Kurtosis & Jar-Bera \\
\hline Ln GR & 1.48 & 1.53 & 2.08 & 0.01 & 0.46 & -1.12 & 4.45 & 11.33 \\
\hline Ln XP & -0.58 & -0.59 & 1.94 & -3.50 & 1.61 & 0.05 & 1.95 & 1.73 \\
\hline Ln IR & 1.87 & 1.90 & 2.63 & 0.64 & 0.47 & -0.44 & 2.60 & 1.47 \\
\hline Ln M2 & 0.14 & 0.22 & 2.40 & -2.40 & 1.53 & -0.02 & 1.87 & 2.00 \\
\hline Ln Inf & 1.91 & 2.00 & 2.63 & 0.92 & 0.46 & -0.41 & 2.06 & 2.47 \\
\hline
\end{tabular}

While, standard deviation shows the dispersion of the data along the equilibrium line indirectly demonstrated the normality. And Figure 2 illustrates the periodic increase from 1978 to 2018. 

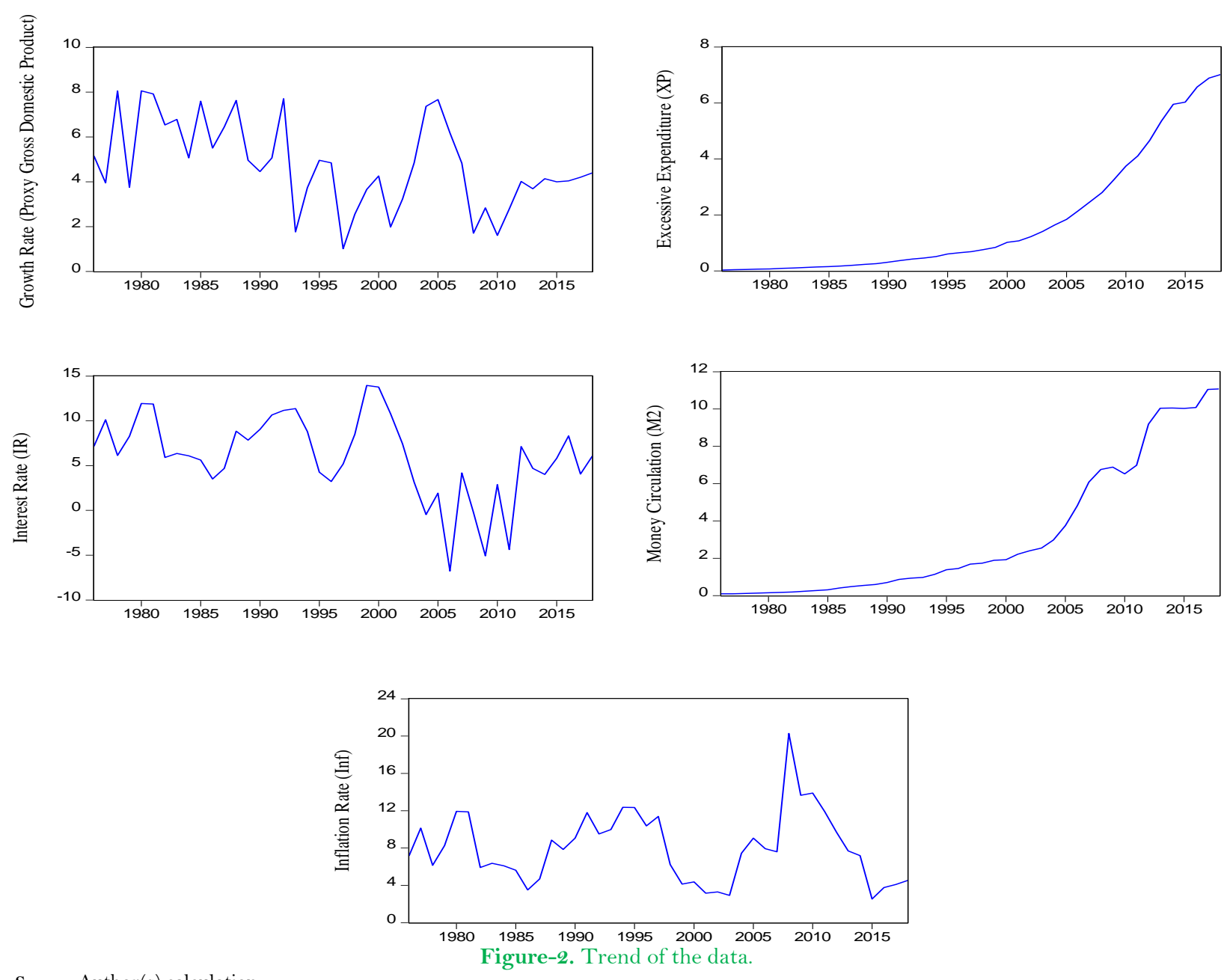

Source: Author(s) calculation.

Whenever the time series data are utilized, it is necessary to make the data stationery i.e. pre- requisite condition. Otherwise the results will be non-reliable. The results of ADF and PP test along with the ZA test are listed in the Table 2 .

\begin{tabular}{c|c|c|c|c|c|c|c|c}
\hline \multicolumn{10}{c|}{ Table-2. ADF test, PP test \& ZA test. } \\
\hline Variable & \multicolumn{2}{|c|}{ ADF test } & \multicolumn{2}{c|}{ PP test } & Lags & Integration order & \multicolumn{2}{c}{ ZA test } \\
\hline & T-stat & Prob & T-stat & Prob & & & T-stat & Break point \\
\hline GR & -9.40 & 0.00 & -18.26 & 0.00 & 1 & $\mathrm{I}(0)$ & -5.63 & 1993 \\
\hline XP & -4.46 & 0.00 & -4.83 & 0.00 & 1 & $\mathrm{I}(0)$ & -4.99 & 2012 \\
\hline IR & -9.42 & 0.00 & -5.78 & 0.00 & 1 & $\mathrm{I}(0)$ & -4.04 & 1988 \\
\hline M2 & 1.84 & 0.00 & -2.7 & 0.01 & 1 & $\mathrm{I}(0)$ & -2.95 & 2006 \\
\hline Inf & -7.865 & 0.00 & -4.72 & 0.00 & 1 & $\mathrm{I}(1)$ & -3.71 & 2008 \\
\hline
\end{tabular}

The outcome states that all the concerning factors are stationary with a same integration order $\mathrm{I}(\mathrm{O})$, except the inflation I(1), meaning that they have zero mean and constant variance. However, the ZA test elaborates the structural break in the data. Such as money circulation has broken in the data in the year 2006, inflation in the 2008, growth rate in the year 1993 and the government excessive expenditure has the structural break in the year 2012.

After a careful inquiry of the stationarity, the Johansen co-integration test was performed. Here point to be noted that lag value plays an important role and also affect the freedom if numbers of lag values are more than the requirement. Therefore, to determine the suitable number of lag values lag length criteria was applied. The results are listed in the Table 3.

Table-3. Lag length criteria.

\begin{tabular}{c|c|c|c|c|c|c}
\hline Lag & LogL & LR & FPE & AIC & SC & HQ \\
\hline 0 & -1342.195 & NA & $4.28 \mathrm{e}+24$ & 70.90498 & 71.12045 & 70.98164 \\
\hline 1 & -1173.692 & $283.7936^{*}$ & $2.27 \mathrm{e}+21^{*}$ & $63.35222^{*}$ & $64.64505^{*}$ & $63.81220^{*}$ \\
\hline
\end{tabular}

The AIC selection criteria are in the favor of one lag and it also explains the goodness of fit. However, conventional methods are not able to investigate and discriminate the true long-run relation and spurious regression because stochastic trend prevails in the data. Therefore, this study utilizes the Johansen (1988) approach for multiple equations to observe the true long-run affiliation. It is expected that this study may have more than one co-integrating equation because model includes more than two variables. For instance, if there are $\mathrm{n}$ variables in the model, there can be $n-1$ co-integrating vectors. The results of trace and Max-eigen presented in the Table 4 and 5. 
Table-4. Trace value.

\begin{tabular}{c|c|c|c|c|c|c}
\hline $\begin{array}{c}\text { Null } \\
\text { hypothesis }\end{array}$ & $\begin{array}{c}\text { Alternative } \\
\text { hypothesis }\end{array}$ & Eigenvalue & $\begin{array}{c}\text { Trace } \\
\text { statistic }\end{array}$ & $\begin{array}{c}\text { 5\% Critical } \\
\text { value }\end{array}$ & Prob.** & $\begin{array}{c}\text { Hypothesized } \\
\text { No. of CE(s) }\end{array}$ \\
\hline $\mathrm{N}_{0}: \mathrm{n}=0$ & $\mathrm{~A}_{1}: \mathrm{n} \leq 1$ & 0.75 & 121.69 & 69.81 & 0.00 & None $^{*}$ \\
\hline $\mathrm{N}_{1}: \mathrm{n} \leq 1$ & $\mathrm{~A}_{1}: \mathrm{n} \leq 2$ & 0.65 & 70.14 & 47.85 & 0.00 & At most $1^{*}$ \\
\hline $\mathrm{N}_{1}: \mathrm{n} \leq 2$ & $\mathrm{~A}_{1}: \mathrm{n} \leq 3$ & 0.29 & 29.79 & 29.79 & 0.04 & At most $2^{*}$ \\
\hline $\mathrm{N}_{1}: \mathrm{n} \leq 3$ & $\mathrm{~A}_{1}: \mathrm{n} \leq 4$ & 0.17 & 15.49 & 15.49 & 0.02 & At most $3^{*}$ \\
\hline \multicolumn{2}{l}{ Source: Author(s) calculations. }
\end{tabular}

Source: Author(s) calculations.

Table-5. Maximum eigen value.

\begin{tabular}{|c|c|c|c|c|c|c|}
\hline $\begin{array}{c}\text { Null } \\
\text { hypothesis }\end{array}$ & $\begin{array}{l}\text { Alternative } \\
\text { hypothesis }\end{array}$ & Eigenvalue & $\begin{array}{c}\text { Max-eigen } \\
\text { statistic } \\
\end{array}$ & $\begin{array}{c}5 \% \text { Critical } \\
\text { value }\end{array}$ & Prob.*** & $\begin{array}{l}\text { Hypothesized } \\
\text { No. of CE(s) }\end{array}$ \\
\hline $\mathrm{N}_{\mathrm{o}}: \mathrm{n}=\mathrm{O}$ & $\mathrm{A}_{1}: \mathrm{n} \leq 1$ & 0.75 & 51.54 & 33.87 & 0.00 & None $*$ \\
\hline $\mathrm{N}_{1}: \mathrm{n} \leq 1$ & $\mathrm{~A}_{1}: \mathrm{n} \leq 2$ & 0.65 & 39.74 & 27.58 & 0.00 & At most $1^{*}$ \\
\hline $\mathrm{N}_{1}: \mathrm{n} \leq 2$ & $\mathrm{~A}_{1}: \mathrm{n} \leq 3$ & 0.29 & 22.13 & 15.26 & 0.04 & At most $2^{*}$ \\
\hline $\mathrm{N}_{1}: \mathrm{n} \leq 3$ & $\mathrm{~A}_{1}: \mathrm{n} \leq 4$ & 0.17 & 6.96 & 3.84 & 0.00 & At most $3^{*}$ \\
\hline
\end{tabular}

The results show that there are four co-integrating equations respectively to their Trace statistic value are greater than $5 \%$ critical value. The results of the Johansen co-integration rank test (max eigenvalue) are given in Table 5. The results of the max-eigen statistic confirm four co-integrating vectors as max-eigen statistic value is greater than $5 \%$ critical value. The Johansen co-integration test confirms that all the variables are co-integrated in the long-run and having long-run relationship.

The study employs the vector error correction model to determine the short-term association. This approach also examines the speed of adjustment i.e. How much time, an explained variable requires to converge the equilibrium after generating fluctuation in the series by some other factor. The analysis is represented in Table 6.

\begin{tabular}{c|c|c|c|c|c}
\multicolumn{7}{c}{ Table-6. Vector error correction model. } \\
\hline Error correction & $\mathbf{D}(\mathbf{G D P})$ & $\mathbf{D}(\mathbf{E X P})$ & $\mathbf{D}(\mathbf{M 2})$ & $\mathbf{D}(\mathbf{I R})$ & $\mathbf{D}(\mathbf{I N F})$ \\
\hline \multirow{2}{*}{ CointEq1 } & -0.283 & -0.039 & 0.018 & 0.002 & -0.884 \\
& $(0.244)$ & $(0.034)$ & $(0.004)$ & $(0.533)$ & $(0.343)$ \\
& {$[-1.160]$} & {$[-1.137]$} & {$[4.56]$} & {$[0.004]$} & {$[-2.578]$} \\
\hline Source: Author(s) calculations.
\end{tabular}

The equation states that gross domestic product and government excessive expenditure converge towards the equilibrium in 1.16 years and 1.13 years' time respectively, while interest rate sharply adjust with the equilibrium, inflation take a time of 2.57 year and $\mathrm{M} 2$ on the other hand takes about 4.5 years' time to attain stabilization in the economy. Moreover, the p-value was determined (Prob 0.04) which is in the favors so we are interested to capture the cumulative influence of all the co-efficient, the study will employ the Wald test, which is utilized to analyze the significance of the explanatory variables in the model. The result is listed in the Table 7.

\begin{tabular}{c|c|c|c}
\multicolumn{4}{c}{ Table-7. Wald test estimations. } \\
\hline Test stat & Value & Df & P value \\
\hline F-statistic & 6.19 & $(1,24)$ & 0.02 \\
\hline Source: Author's calculation.
\end{tabular}

The results states that explanatory variable in the model are significant and cumulatively affect the dependent factor. The most important thing is to find out the granger causality, either variables granger causes each other and in what direction. The results are presented in the Table 8.

Table-8. Granger causality.

\begin{tabular}{|c|c|c|c|}
\hline Null hypothesis: & F-statistic & Prob. & Conclusion \\
\hline Ln XP does not Granger cause Ln GR & 3.62108 & 0.0645 & Uni-direction \\
\hline Ln GR does not Granger cause Ln XP & 0.13905 & 0.7112 & \\
\hline Ln IR does not Granger cause Ln GR & 0.40674 & 0.5285 & \\
\hline Ln GR does not Granger cause Ln IR & 0.07877 & 0.7809 & \\
\hline Ln M2 does not Granger cause Ln GR & 4.40419 & 0.0424 & Uni-direction \\
\hline Ln GR does not Granger cause Ln M2 & 3.03599 & 0.0893 & \\
\hline Ln Inf does not Granger cause Ln GR & 0.65798 & 0.4222 & \\
\hline Ln GR does not Granger cause Ln Inf & 0.94644 & 0.3366 & \\
\hline Ln IR does not Granger cause Ln XP & 1.79935 & 0.1899 & \\
\hline Ln XP does not Granger cause Ln IR & 1.14659 & 0.2928 & \\
\hline Ln M2 does not Granger cause Ln XP & 6.11029 & 0.0179 & Uni-direction \\
\hline Ln XP does not Granger cause Ln M2 & 2.38683 & 0.1304 & \\
\hline Ln Inf does not Granger cause Ln XP & 0.30884 & 0.5816 & \\
\hline Ln XP does not Granger cause Ln Inf & 0.41445 & 0.5235 & \\
\hline Ln M2 does not Granger cause Ln IR & 0.88714 & 0.3538 & \\
\hline Ln IR does not Granger cause Ln M2 & 0.00136 & 0.9708 & \\
\hline Ln Inf does not Granger cause Ln IR & 0.00035 & 0.9852 & \\
\hline Ln IR does not Granger cause Ln Inf & 0.01891 & 0.8916 & \\
\hline Ln Inf does not Granger cause Ln M2 & 0.00355 & 0.9528 & \\
\hline Ln M2 does not Granger cause Ln Inf & 0.25128 & 0.6192 & \\
\hline
\end{tabular}

Source: Author(s) calculation. 
The results elaborate that XP granger cause the GR with the direction from XP towards the GR, M2 granger cause the GR with the direction from $\mathrm{M} 2$ towards the GR and $\mathrm{M} 2$ granger cause the XP with the direction from $\mathrm{M} 2$ towards the XP. All have the one-way causality from XP to GR, M2 to GR and M2 to XP.

In order to examine the reliability and stability of the model, the study employ the six residual diagnostic tests. Results of diagnostic tests are presented in Table 9. The autoregressive conditional heteroskedasticity (ARCH) (Engle, 1982) and Breusch-Godfrey serial correlation LM (Breusch, 1978; Godfrey, 1978) tests conclude that the results of ARDL model are free from problems of heteroscedasticity and serial correlation as in both cases, probability value is greater than 0.05. Here, the null hypotheses of homoscedasticity and no serial correlation are accepted. The Ramsey RESET test (Ramsey, 1969) confirmed that the model was correctly specified as this test probability value is greater than 0.05. The Jarque and Bera (1987) test was applied to check that the residual terms are normally distributed or not. The null hypothesis of normal distribution was accepted as probability value is greater than 0.05 .

Table-9. Diagnostic tests.

\begin{tabular}{|c|c|c|}
\hline \multicolumn{3}{|c|}{ ARCH test } \\
\hline$X^{2}-$ Statistics & Degree of freedom & Prob \\
\hline & 1 & 0.34 \\
\hline \multicolumn{3}{|c|}{ Breusch- Godfrey serial correlation LM test } \\
\hline$X^{2}-$ Statistics & Degree of freedom & Prob \\
\hline & 1 & 0.67 \\
\hline \multicolumn{3}{|c|}{ Ramsey RESET test } \\
\hline$F-$ Statistics & Degree of freedom & Prob \\
\hline 16.62 & $(1,39)$ & 0.15 \\
\hline \multicolumn{3}{|c|}{ Jarque-Bera test } \\
\hline$F-$ Statistics & Degree of freedom & Prob \\
\hline 1.24 & $(2.34)$ & 0.69 \\
\hline
\end{tabular}

Figure 3 and 4 shows the CUSUM and the CUSUMSQ tests of parameter stability, respectively. The straight line represents the critical bound at 5\% significance level. The null hypothesis of stable parameters is accepted against the alternative hypothesis of unstable parameters as the plots of CUSUM and CUSUMSQ statistic fall within the $5 \%$ significance level. This confirms that the short-run and long-run parameters of the model are stable and reliable.

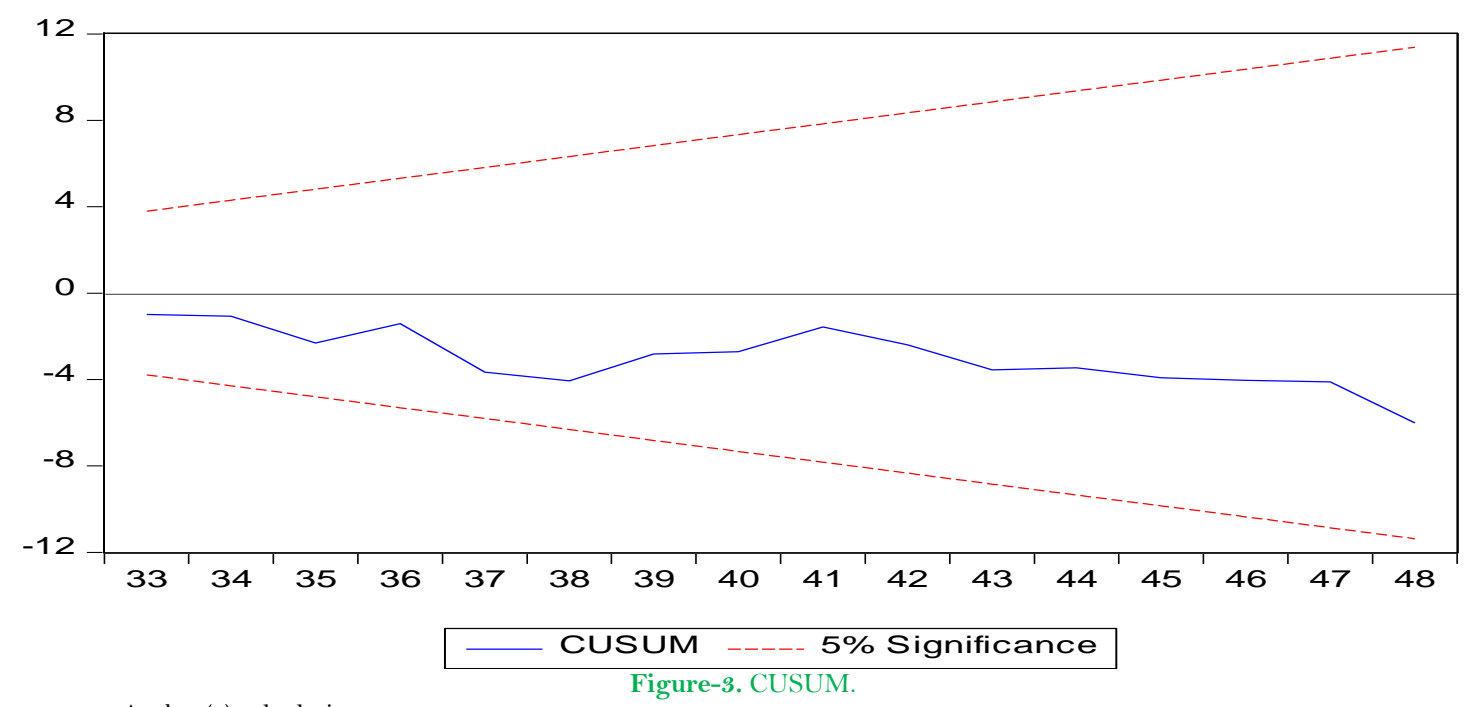

Source: Author(s) calculation.

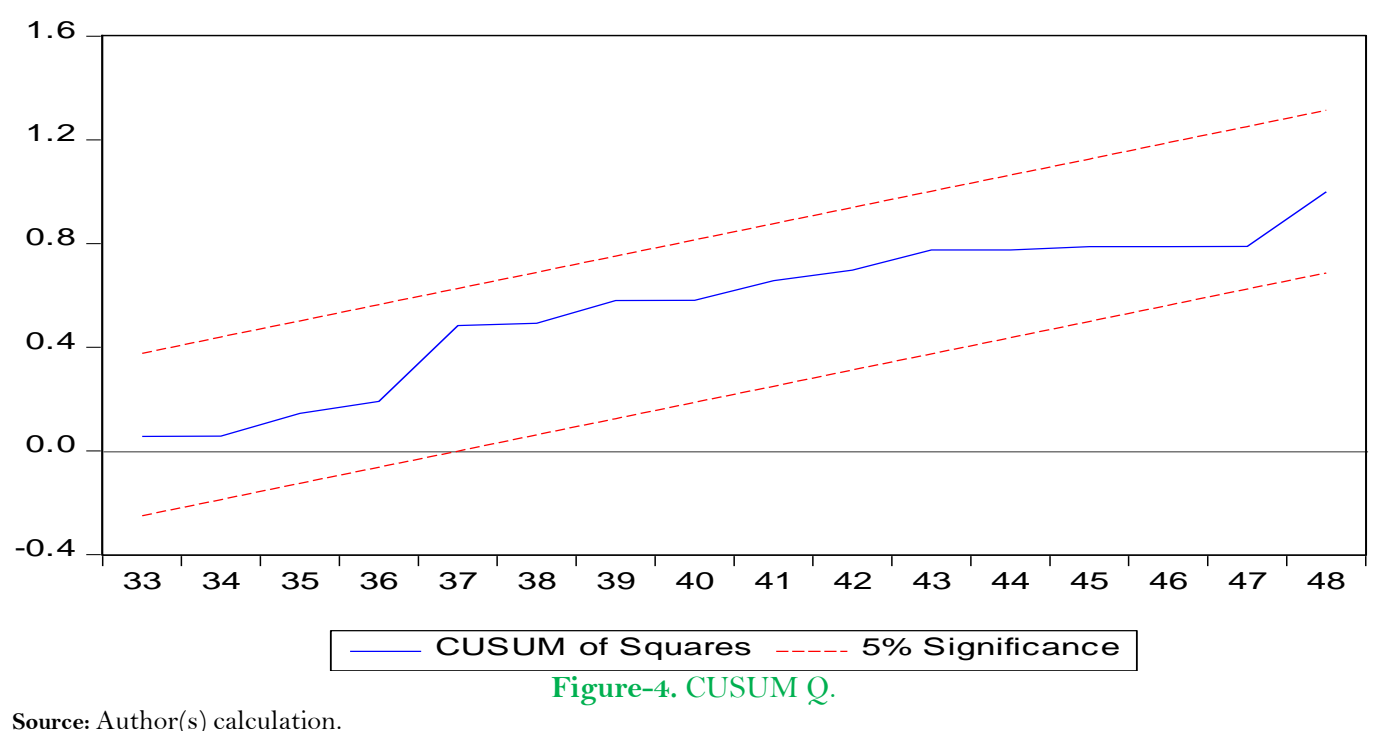

Source: Author(s) calculation. 
Now study employs the vector auto-regressive (VAR), which was presented by Sims (1980) to determine the vigorous and fluctuating interlink among the variables. The VAR model explores the hidden information in the data and economist use it to conduct some type of experiments to change the direction of the variable in the economy and also to re-arrange the policy factors. The results are presented in Table 10.

\begin{tabular}{c|c|c|c|c|c}
\multicolumn{7}{c}{ Table-10. Vector auto-regressive result. } \\
\hline Variables & GR & XP & INF & M2 & IR \\
\hline \multirow{3}{*}{ GR $(1)$} & 0.012 & 0.002 & -0.029 & -0.008 & 0.140 \\
& $(0.19)$ & $(0.019)$ & $(0.169)$ & $(0.028)$ & $(0.149)$ \\
& {$[-0.06]$} & {$[0.483]$} & {$[-0.176]$} & {$[-0.295]$} & {$[-0.940]$} \\
\hline
\end{tabular}

It is very problematic directly, to explore the estimations i.e. Impulse response function (IRF) is there to explain the results. Although this method shows that all the variable inflation, excessive expenditure, growth rate, interest rate and the money in circulation are connected with each other. The IRF elaborates that when a fluctuation is produced by changing the level of a variable in the economy, then it creates a shock wave which pass through the whole and every sector of the economy and have some type of influence on growing process. This shock not only divert the course of a variable in the present atmosphere, but also influence the other factors in the economy in the future. Moreover, IRF measures the response generated by some external disturbance i.e. Interest Rate, money in circulation, inflation and excessive expenditure. The results of IRF are listed in Figure 5.

Response to Cholesky One S.D. (d.f. adjusted) Innovations \pm 2 S.E.
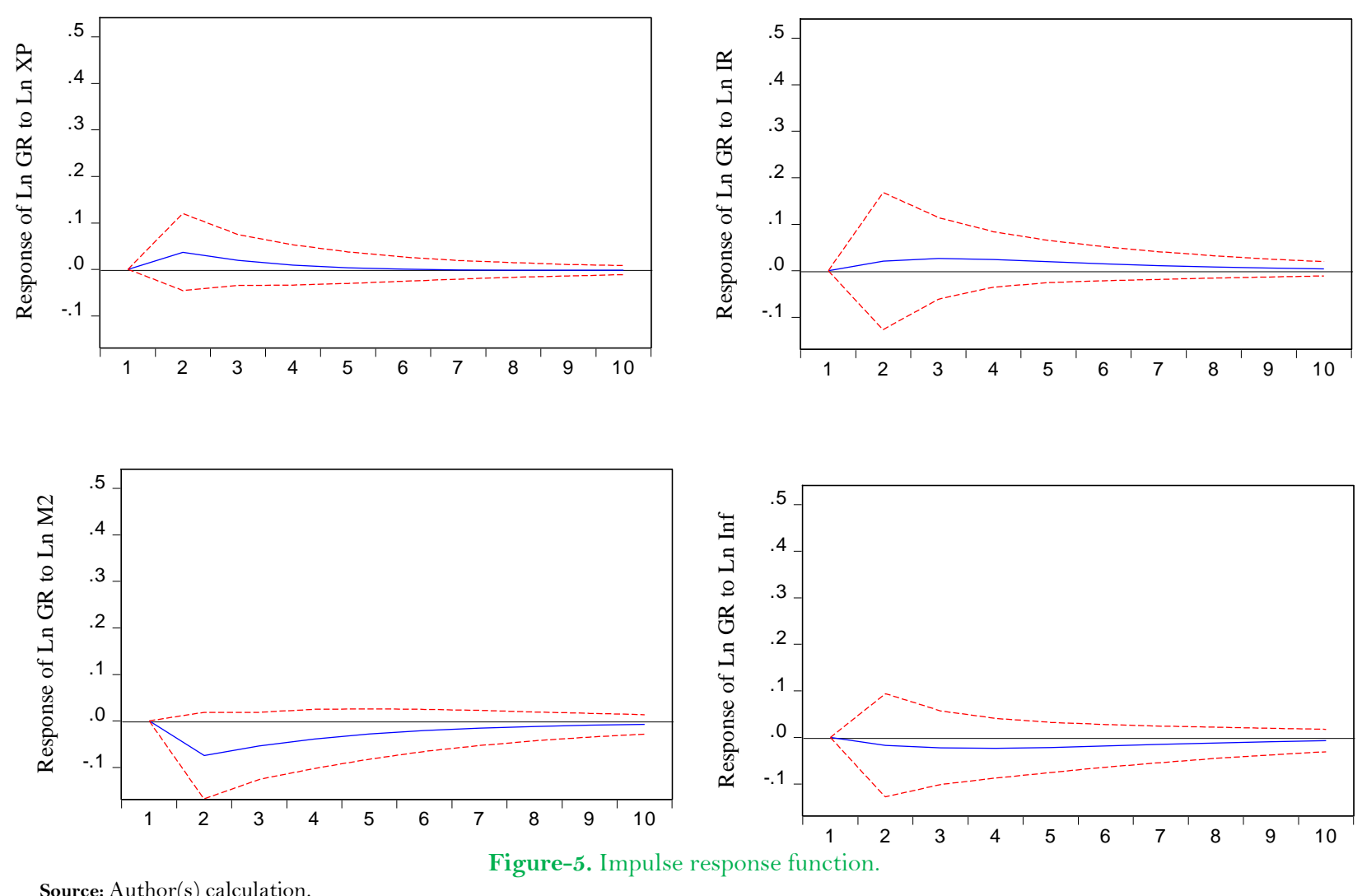

Source: Author(s) calculation.

The estimations state that when a contemporaneous shock of excessive expenditure is given to the growth rate, initially the growth rate would increase till second period, then starts to move towards the equilibrium and become closer and closer with every passing year until attaining equilibrium in the fifth period. Simply we can say that when government fluctuate the level of its spending, then growth rate starts to move positively, after some time growth starts to increase and would attain the equilibrium in the long term.

When a standard deviation shock of interest rate is given to the growth rate, initially growth rate increase with increasing rate till the 3 rd year after that starts to decrease with decrease rate and attain equilibrium in the $7^{\text {th }}$ year and moves along with the equilibrium line. In other words, when the government changes the level of interest ratio, then the growth rate of the economy increased positively throughout the time frame.

While money supply fluctuates then it creates a shock wave which hits the economy. Then the growth rate initially responds positively, then moves away from the equilibrium in the negative direction till $2^{\text {nd }}$ year after that growth ratio increase with the increasing rate in such a way that every year it becomes closer and closer towards the equilibrium state. And in the case of inflation, contemporaneous shock wave which is generated by the inflation. Growth rate initially responds positively and the moves below the equilibrium, but closely and after that, remain there closer and closer towards the equilibrium state.

Let's compare the finding of his work to the findings of the other authors from the world, 110 economies from the world have experiencing the co-relation of output and the money circulating (money supply), however in the perspective of this paper Pakistan is also included in the 110 economies of the world (Herwartz and Reimers, 2006). Pakistan is facing the impact on interest rate on excessive expenditure is negative just as the Sweden, Greece, Nigeria, India and America while resembling with the Germany, India and Japan in the context of GDP and interest rate (Waqas and Awan, 2012; Purusothaman, 2013). 


\section{Conclusion and Suggestions}

Every economy of the world is facing the problem of inflation, interest rate, money supply and excessive expenditures, which in turn influence the growth rate, either it is developed or the emerging one. The difference is that the influence of these factors in the emerging economy is strong as compared to the developed countries.

The objective of the study is to investigate that excessive expenditure of the government affects the interest rate and circulation of the money which in turn influence the growing process. For this purpose, time series data comprises on 1976 to 2018 were collected from Handbook of statistics and the world development indicator. To determine the zero mean and constant variance ADF and PP test were employed and to capture the data break in the variables ZA test was utilized. And confirms the stationery in the data incorporated with data break in different time periods. However, to determine the short and long-term association among the interest rate, inflation, growing rate, excessive expenditure and money supply, VECM and Johansen cointegration test were used.

The results of VECM and Johansen cointegration elaborate that all the concerning variables are connected with each other in the short as well as in the long term along with the zero mean and constant variance while having a structural break in the data with different time frame. Moreover, the study also determines that the explanatory variables are significant, the model is stable, residual is free from auto-correlation and the model is normal.

However, to capture the fluctuation study utilizes the impulse response function. The result depicts that if a shock of excessive government expenditure, inflation, money circulation and interest rate are given to the growth rate then the response of growth rate in the case of expenditure and interest rate would be positive while in the case of the money circulation and the inflation would be negative in the future. There are some suggestions.

The government should control its expenditure which in turn increases the level of interest rate in the economy. The interest rate is the key to attract the capital outside the economy, but government should not create the atmosphere of crowding out. When an expenditure is increased no doubt, GDP increased, but inflation and interest rate also increase, so government adopts the strategy which tries to maintain the favorable level of both inflation and interest rate.

\section{Reference}

Abou, M.S., 2014. Testing the relationship between money supply and GDP in Bahrain. International Journal of Economics, Commerce and Management, 5(2): 1-16

Adefeso, H. and H. Mobolaji, 2010. The fiscal-monetary policy and economic growth in Nigeria: Further empirical evidence. Pakistan Journal of Social Sciences, 7(2): 137-142.Available at: https://doi.org/10.3923/pjssci.2010.137.142.

Aqeel, A., M. Nishat and A. Qayyum, 2000. The twin deficits phenomenon: Evidence from Pakistan [with Comments]. The Pakistan Development Review, 39(4II): 535-550.Available at: https://doi.org/10.30541/v39i4iipp.535-550.

Ari, A., 2012. Early warning systems for currency crises: The Turkish case. Economic Systems, 36(3): 391-410.Available at: https://doi.org/10.1016/j.ecosys.2012.07.001.

Bonga-Bonga, L., 2012. Budget deficit and long-term interest rates in South Africa. African Journal of Business Management, 6(11): 39543961.Available at: https://doi.org/10.5897/ajbm11.713.

Breusch, T.S., 1978. Testing for autocorrelation in dynamic linear models. Australian Economic Papers, 17(31): 334-355.Available at: https://doi.org/10.1111/j.1467-8454.1978.tbo0635.x.

Burney, N.A., A. Yasmeen and M.K. Niazi, 1989. Government budget deficits and interest rates: An empirical analysis for Pakistan [with Comments]. The Pakistan Development Review, 28(4): 971-980.

Chakraborty, L., 2012. Determination of interest rate in India: Empirical evidence on fiscal deficit-interest links and financial crowding out. National Institute of Public Finance and Policy, New Delhi, Working Paper, 744: 1-24.

Eisner, R., 1992. Deficits: Which, how much, and so what? The American Economic Review, 82(2): 295-298.

Engle, R.F., 1982. Autoregressive conditional heteroscedasticity with estimates of the variance of United Kingdom inflation. Econometrica: Journal of the Econometric Society, 50(4): 987-1007.Available at: https://doi.org/10.2307/1912773.

Feldstein, M., 1982. Government deficits and aggregate demand. Journal of Monetary Economics, 9(1): 1-20.Available at: https://doi.org/10.1016/0304-3932(82)90047-2.

Godfrey, L.G., 1978. Testing against general autoregressive and moving average error models when the regressors include lagged dependent variables. Econometrica: Journal of the Econometric Society, 46(6): 1293-1301.Available at: https://doi.org/10.2307/1913829.

Gupta, R. and J. Uwilingiye, 2008. Measuring the welfare cost of inflation in South Africa. South African Journal of Economics, 76(1): 1625.Available at: https://doi.org/10.1111/j.1813-6982.2008.00159.x.

Haque, N.U. and P.J. Montiel, 1994. Pakistan: Fiscal sustainability and macroeconomic policy. Public Sector Deficits and Macroeconomic Performance: $413-457$.

Herbert, M. and N. Saher, 2010. Response of long-term interest rate to fiscal imbalance: Evidence from Pakistan. SBP Research Bulletin, 6: $43-49$.

Herwartz, H. and H.E. Reimers, 2006. Long-run links among money, prices and output: Worldwide evidence. German Economic Review, 7(1): 65-86.Available at: https://doi.org/10.1111/j.1468-0475.2006.00147.x.

Hubbard, G., 2012. Consequences of government deficits and debt. International Journal of Central Banking, 8(S1): 203-235.

Idris, J., Z. Yusop and M.S. Habibullah, 2016. Trade openness and economic growth: A causality test in panel perspective. International Journal of Business and Society, 17(2): 281.

Ihsan, I. and S. Anjum, 2013. Impact of money supply (M2) on GDP of Pakistan. Global Journal of Management and Business Research, $13(6): 1-8$.

Jarque, C.M. and A.K. Bera, 1987. A test for normality of observations and regression residuals. International Statistical Review, 55(2): 163172.Available at: https://doi.org/10.2307/1403192.

Jillani, S. and M. Asim, 2010. Exploring impact of macro-economic variables on GDP of Pakistan. IBT Journal of Business Studies, 6(2): 6573.

Johansen, S., 1988. Statistical analysis of cointegration vectors. Journal of Economic Dynamics and Control, 12(2-3): 231-254.Available at: https://doi.org/10.1016/0165-1889(88)90041-3.

Kameda, K., 2008. Budget deficits, government debt and interest rates in Japan: An. Journal of Monetary Economics, 20(2): $281-300$.

Karapetyan, L. and L. Harutyunyan, 2013. The development and the side effects of remittances in CIS countries: The case of Armenia. Research Report CARIM-East RR 2013/24.

Karapetyan, L. and L. Harutyunyan, 2013. The development and the side effects of remittances in CIS countries: The case of Armenia. Research Report CARIM-East RR 2013/24.

Kewal, S.S., 2012. Influence of inflation, interest rates, exchange rates and GDP growth on the composite stock price index. Economia Journal, 8(1): 53-64.

Kirchner, S., 2007. Fiscal policy and interest rates in Australia. Policy: A Journal of Public Policy and Ideas, $23(3): 11$.

Muelbauer, J. and L. Nunziata, 2001. Credit, the stock market and oil. University of Oxford, Working Paper.

Mukhtar, T. and M. Zakaria, 2008. Budget deficits and interest rates: An empirical analysis for Pakistan. Journal of Economic Cooperation, 29(2): 1-14. 
Muñoz, E., A. Laughlin, D.M. Regan, I. Teicher, I.B. Margolis and L. Wise, 1985. The financial effects of emergency department-generated admissions under prospective payment systems. JAMA, 254(13): 1763-1771.Available at: https://doi.org/10.1001/jama.254.13.1763.

Noula, A.G., 2012. Fiscal deficit and nominal interest rate determination in Cameroon: An application of the loanable funds model. Global Advanced Research Journal of Management and Business Studies, 1(1): 6-29.

Nwaogwugwu, I. and O. Evans, 2016. A sectoral analysis of fiscal and monetary actions in Nigeria. The Journal of Developing A reas, 50(4): 21 1-230.Available at: https://doi.org/10.1353/jda.2016.0162.

Purusothaman, U.R., 2013. A case study on growth of investment in life insurance in India. TRANS Asian Journal of Marketing \& Management Research, 27(4): 26-36.

Ramey, V.A., 2011. Identifying government spending shocks: It's all in the timing. The Quarterly Journal of Economics, 126(1): 150.Available at: https://doi.org/10.1093/qje/qjq008.

Ramsey, J.B., 1969. Tests for specification errors in classical linear least-squares regression analysis. Journal of the Royal Statistical Society: Series B (Methodological), 31(2): 350-371.Available at: https://doi.org/10.1111/j.2517-6161.1969.tbo0796.x.

Rangarajan, C. and D.K. Srivastava, 2005. Fiscal deficits and government debt: Implications for growth and stabilisation. Economic and Political Weekly: 2919-2934.

Samimi, A.J. and B.S. Jamshid, 2011. Budget deficit and inflation: A sensitivity analysis to inflation and money supply in Iran. Middle-East Journal of Scientific Research, 8(1): 257-260.

Santosa, A.B., 2017. Analysis of inflation in Indonesia. Prosiding Seminar Nasional Multi Disiplin Ilmu \& Call for Papers, 3(1): 445-452

Saymeh, A.A.F. and M.M.A. Orabi, 2013. The effect of interest rate, inflation rate, GDP, on real economic growth rate in Jordan. Asian Economic and Financial Review, 3(3): 341-354.

Schabert, A., 2005. Money supply and the implementation of interest rate targets. ECB Working Paper, No. 483, European Central Bank (ECB).

Sims, C.A., 1980. Macroeconomics and reality. Econometrica: Journal of the Econometric Society, 48(1): 1-48.

Sims, C.A., 1986. Are forecasting models usable for policy analysis? Quarterly Review, 10(1): 2-16.

Tabar, F.J., Z. Najafi and Y.S. Badooei, 2016. The relationship between money supply, prices, government expenditures and economic growth in Iran economy. International Journal of Humanities and Cultural Studies (IJHCS) ISSN 2356-5926: 483-495.

Waqas, M. and M.S. Awan, 2012. Exchange rate, interest rate and Ricardian equivalence evidence from Pakistan. The Romanian Economic Journal, 15(46): 249-270. 